\title{
ANALISIS PENGARUH PEMERINTAH TERHADAPINDEKS PEMBANGUNAN MANUSIA DI JAWA TIMUR
}

\author{
Syivai Aviyati \\ Susilo \\ Pasca Sarjana Ilmu Ekonomi Universitas Brawijaya Malang \\ Email: syivai.syivai@gmail.com
}

\begin{abstract}
Human development has always been as the main topic of sustainable development. Improving the human quality as responsibility of all people, especially the government in term of allocation roles to provide different types of services such as education facilities, health and road infrastructure. The Social indicators to measure the success of human development used the human development index. This study empirically analyze the effect of health expenses, education and road infrastructure as well as the growth of the population as a control variable to the index of human development in the District/City of East Java. Data were collected from 29 districts and 9 Cities of the year 2007-2012. To analyze the panel data of district/City, we use a fixed effect model (FEM). We found a statistically significant and positive effect between government expenses on education and government expenses in the health sector to the index of human development, while government expenses in infrastructure and population growth have no significant influence to the index of human development but have a positive direction.
\end{abstract}

Keywords: government expenses population growth and human development index

Pembangunan manusia merupakan indikator utama dalam mengukur tingkat kesejahteraan masyarakat UNDP, (1990). Sehingga orientasi yang ditekankan dalam pembangunan tidak hanya berfokus pada pertumbuhan ekonomi, tetapi lebih kepada manusia untuk mencapai pembangunan berkelanjutan (Hamzah, et al., 2012). Peningkatan sumber daya manusia bertujuan untuk memperluas pilihan dan kesempatan masyarakat, meningkatkan hidup sehat melalui keterampilan yang diperoleh, dan pengetahuan yang akhirnya dapat meningkatkan pertumbuhan Produk Domestik Bruto (PDB) melalui peningkatan produktivitas. Sehingga sumber daya manusia dari suatu bangsa merupakanfaktor paling menentukan karakter dan kecepatan pembangunan sosial dan ekonomi (Todaro, 2006).

Beberapa argumentasi teoritis mengemukakan bahwa terdapat pengaruh positif antara pengeluaran pemerintah terhadap IPM. Seperti yang diungkapkan Rajkumar (2008), Ranis (2010), Saraswati (2012), Fattah (2012), Craigwell (2012), Razmi (2012) dan Kim (2013) yang melakukan penelitian di berbagai negara maju dan berkembang telah menunjukkan bahwa alokasi pengeluaran pemerintah yang efisien dan memadai untuk pendidikan dan kesehatan dapat meningkatkan pembangunan manusia dan pertumbuhan ekonomi serta mengurangi beban kemiskinan. Namun demikian, terdapat beberapa pandangan lain yang melihat bahwa pengeluaran pemerintah yang besar tidak selalu diikuti oleh peningkatan IPM yang signifikan. Badrudin (2011) menemukan bahwa IPM yang tinggi di Propinsi Daerah Istimewa Yogyakarta, bukan semata-mata disebabkan oleh kenaikan pengeluaran pemerintah, akan tetapi lebih disebabkan oleh sense of educationyang dimiliki oleh masyarakat itu sendiri. Hamzah, et al. (2012) yang meneliti 26 propinsi di Indonesia juga mengungkapkan bahwa pengeluaran pemerintah pengeluaran pemerintah sektor kesehatan memiliki pengaruh yang tidak signifikan terhadap IPM.

Berdasarkan dua pandangan tersebut, maka penting untuk melihat bagaimana pengaruh pengeluaran pemerintah terhadap peningkatan IPM di Jawa Timur. Dengan alasan, Jawa Timur merupakan salah satu propinsi dengan jumlah kabupaten dan kota terbanyak dengan tingkat pertumbuhan ekonomi yang tinggi bahkan di atas nasional, namun jika dilihat pada indikator pembangunan yang menggunakan IPM hasilnya 
sangat kontradiktif. IPM Jawa Timur selalu di bawah nasional.

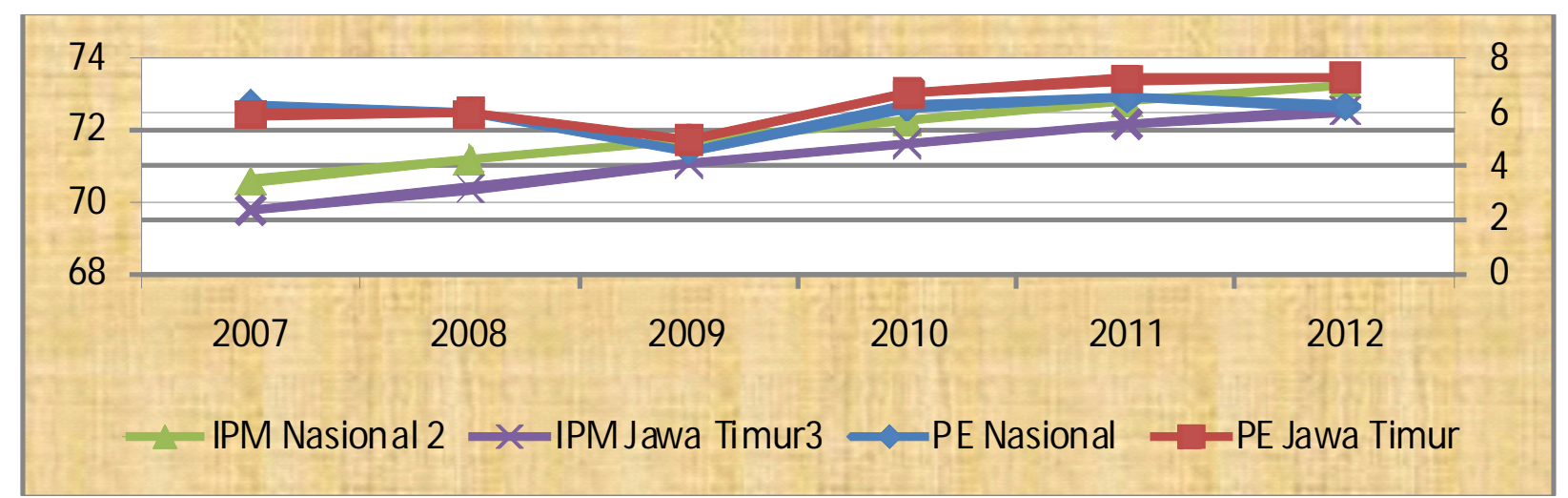

Gambar 1. Perkembangan Pertumbuhan Ekonomi (PE) dan IPM Jawa Timur dan Nasional Tahun 2007-2012 Sumber: BPS Jatim, 2012 (data diolah)

Dengan melihat latar belakang di atas, maka tujuan dalam penelitian ini yaitu Untuk menganalisis pengaruh pengeluaran pemerintah di bidang pendidikan, bidang kesehatan dan bidang infrastruktur terhadap peningkatan IPM di Kabupaten/Kota Jawa Timur.

\section{Pembangunan Manusia dan Indeks Pembangunan Manusia (IPM)}

Pentingnya pembangunan manusia sangat ditekankan dalam teori pertumbuhan endogen. Menurut teori ini dengan adanya spesialisasi dan investasi di bidang sumber daya manusia, maka akumulasi modal tidak mengalami diminishing return, tetapi justru mengalami increasing return Todaro (2006). Pembangunan manusia didasarkan pada tiga tujuan akhir pembangunan: masa hidup (longevity) diukur dengan usia harapan hidup, pengetahuan (knowledge) yang diukur dengan kemampuan baca tulis orang dewasa secara tertimbang dan rata-rata tahun bersekolah, serta standar kehidupan (standard of living) yang diukur dengan pendapatan riil per kapita, disesuaikan dengan paritas daya beli (purchasing power parity atau PPP) untuk mencerminkan biaya hidup.

Indikator sosial yang biasa dipakai untuk mengukur tiga tujuan akhir pembangunan tersebut adalah Indeks Pembangunan Manusia (IPM) atau HDI (Human Development Index). Indeks Pembangunan Manusia (IPM) yang dikembangkan oleh pemenang Nobel asal India Amartya Sen dan Mahbub ul Haq yang dibantu oleh Gustav Ranis pada tahun 1990, ini memberikan gambaran seberapa jauh suatu wilayah telah mencapai sasarannya yang ditentukan yaitu angka harapan hidup 85 tahun, pendidikan dasar bagi semua lapisan masyarakat tanpa terkecuali dan tingkat pengeluaran konsumsi yang telah mencapai standar hidup layak.

\section{Peran Pemerintah dalam Pembangunan Manusia melalui Alokasi Anggaran}

Tercapainya tujuan pembangunan manusia yang tercermin pada Indeks Pembangunan Manusia (IPM) sangat tergantung komitmen pemerintah sebagai penyedia sarana penunjang.Pembangunan tiga aspek yang menjadi fokus perhatian dalam penghitungan IPM tidak dapat berdiri sendiri dan membutuhkan sinergi di antara ketiganya. (Anand, 1993 dalam Badrudin, 2011).

Diharapkan agar local government spending akan benar-benar bermanfaat dan menjadi stimulus fiskal bagi perekonomian di daerah dalam rangka mewujudkan kesejahteraan masyarakatnya melalui peningkatan kualitas hidupnya. Oleh karena itu, strategi alokasi pengeluaran pemerintah perlu dioptimalkan pada bidang kesehatan, pendidikan, dan pembangunan infrastruktur. Kebijakan pemerintah untuk meningkatkan kualitas hidup dapat meliputi: (1) Pengembangan pendidikan untuk memenuhi tuntutan pasar kerja sesuai dengan kebutuhan (demand driven), (2) Pembangunan kesehatan difokuskan untuk memperluas cakupan dan kualitas pelayanan kesehatan terutama untuk daerah-daerah miskin dan terpencil, (3) Peningkatan kualitas hidup orang miskin dengan memberikan keterampilan praktis untuk mendorong semangat kemandirian dan kemerdekaan, (4) Penyediaan infrastruktur untuk meningkatkan mobilitas produksi, kegiatan ekonomi dan sosial warga negara, dan (5) Mengurangi laju pertumbuhan penduduk dengan mengurangi kepadatan penduduk dengan cara pemerataan distribusi populasi (Fattah, 2012). 


\section{Pengeluaran Pemerintah di Bidang Pendidikan}

Amanat dari Undang-Undang Dasar 1945 menekankan bahwa setiap warga negara mempunyai hak yang sama untuk memperoleh pendidikan dan dalam Undang-Undang Nomor 20 Tahun 2003 mengatur besarnya dana pendidikan selain gaji pendidik dan biaya pendidikan kedinasan mendapat alokasi minimal 20\% dari Anggaran Pendapatan dan Belanja Negara atau Daerah (APBN/APBD).

Moore (2006) dalam Craigwell (2012) dan Gupta, et al. (2004), menemukan bahwa pengeluaran pemerintah dalam bidang pendidikan dapat mempercepat pencapaian pendidikan. Dengan adanya perbaikan tingkat pendidikan menyebabkan penurunan tingkat kemiskinan dan peningkatan standar hidup sehingga memiliki dampak pada output ekonomi. Menurut Guisan (2009) dalam Guisan, (2010)efek utama dari investasi pendidikan untuk meningkatkan kepuasan hidup di negara-negara kurang berkembang. Di samping itu, pendidikan juga memiliki efek positif pada indeks kualitas pemerintahan, yang juga berkontribusi pada peningkatan PDB riil per kapita.

\section{Pengeluaran Pemerintah di Bidang Kesehatan}

Pengeluaran pemerintah bidang kesehatan memiliki satu tujuan, yakni untuk meningkatkan derajat kesehatan masyarakat, yang dapat diukur dengan: (i) penurunan angka kematian bayi; (ii) penurunan angka kematian di bawah 5 tahun; dan (iii) peningkatan angka harapan hidup. Dalam Undang-Undang Nomor 36 Tahun 2009 Tentang Kesehatan mengatur besarnya anggaran kesehatan pemerintah dialokasikan minimal sebesar 5\% (lima persen) dari anggaran pendapatan dan belanja negara di luar gaji; besar anggaran kesehatan pemerintah daerah provinsi, kabupaten/kota dialokasikan minimal 10\% (sepuluh persen) dari anggaran pendapatan dan belanja daerah di luar gaji.

Pentingnya peningkatan derajat kesehatan masyarakat dalam peningkatan kualitas hidup manusia telah dibuktikan oleh Schultz (1961) dalam Craigwell (2012), mengatakan bahwa kesehatan telah menjadi dasar untuk mencapai pertumbuhan yang lebih cepat dalam masyarakat Barat. Mendapatkan standar tinggi kesehatan adalah hak asasi setiap orang dan juga dasar untuk mengurangi ketimpangan sosial-ekonomi (Backman, et al., 2008). Ketersediaan, akses yang tepat dan keterjangkauan pelayanan kesehatan merupakan dasar-dasar kesehatan yang lebih baik, dan mengurangi beban keuangan mayoritas penduduk (WHO, 2010 dalam Khausal, 2013). Rajkumar (2008), menunjukkan bahwa pengeluaran pemerintah di bidang kesehatan memiliki pengaruh negatif pada kematian anak di negara-negara dengan pemerintahan yang baik, birokrasi dengan kualitas tinggi dan tingkat korupsi yang rendah. Pengeluaran kesehatan dapat meningkatkan pembangunan manusia melalui dua saluran: (i) pertumbuhan ekonomi; dan (ii) mengurangi tingkat kematian serta meningkatkan proses pembelajaran. Promosi kesehatan dapat meningkatkan kualitas manusia melalui akumulasi modal kesehatan, dan memiliki efek langsung pada pertumbuhan. Selain itu, peningkatan kesehatan dapat meningkatkan produktivitas tenaga kerja melalui peningkatan umur panjang dan hari kerja yang secara tidak langsung mempengaruhi produksi (Razmi, 2012).

\section{Pengeluaran Pemerintah di Bidang Infrastruktur}

Pengeluaran pemerintah melalui pembangunan berbagai macam infrastruktur yang tepat diharapkan mampu menambah kapasitas ekonomi dengan memberikan efek multiplier. Dalam penelitian ini, data infrastruktur yang dipakai adalah pengeluaran pemerintah pada jalan. Dengan alasan, bahwa jalan sebagai bagian sistem transportasi nasional yang mempunyai peranan penting terutama dalam mendukung ekonomi, sosial budaya, lingkungan, politik, serta pertahanan dan keamanan.(UU RI Nomor 38 Tahun 2004).

Prud'homme (2004) dan Kusharjanto (2011), telah menunjukkan bahwa infrastruktur publik memiliki efek positif dan signifikan secara statistikatas penghasilan pribadi per kapita. keberadaan jalan merupakan urat nadi perekonomian, selain dapat membantu kelancaran mobilitas penduduk karena jalan mempunyai manfaat meningkatkan arus distribusi barang dan jasa produk yang dihasilkan untuk mencapai atau memasuki pasar yang lebih luas yang memungkinkan terpenuhinya kebutuhan dan manfaat yang lebih besar bagi para konsumen dan masyarakat pada umumnya, sehingga memungkinkan terjadinya pasar yang lebih luas dan konsentrasi produksi yang lebih besar dalam kaitan dengan usaha ekonomi skala besar.

\section{Hubungan Pengeluaran Pemerintah terhadap IPM}

Menurut Mangkoesoebroto (2012), secara mikro pengeluaran pemerintah (goverment expenditure) adalah untuk menganalisis faktor-faktor yang menimbulkan permintaan akan barang publik dan faktorfaktor yang mempengaruhi tersedianya barang publik. Interaksi antara permintaan dan penawaran untuk 
barang publik menentukan jumlah barang publik yang akan disediakan melalui anggaran belanja. Jumlah barang publik yang akan disediakan tersebut selanjutnya akan menimbulkan permintaan akan barang lain. Secara teoritis efek pengeluaran pemerintah jika dihubungkan dengan konsep kendala anggaran (budget constraints) dapat dijelaskan sebagai berikut:

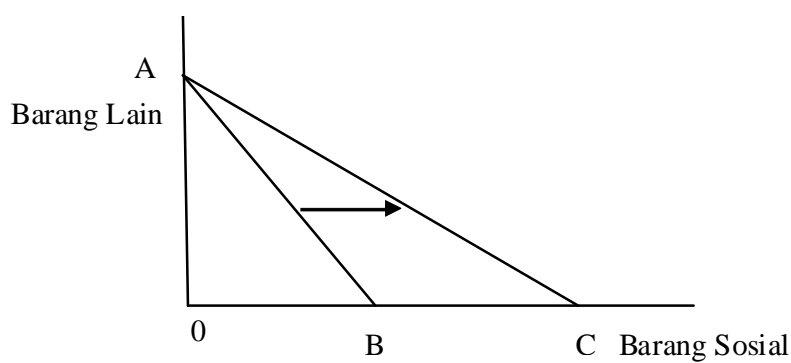

Gambar 2. Perubahan Budget Constraints KarenaAdanya Sumber: Sadono Sukirno

Semula dengan anggaran tertentu area konsumsi berada pada pilihan yang dibatasi oleh garis anggaran AB. Adanya pengeluaran pemerintah untuk barang sosial, misalnya: subsidi untuk meringankan sekolah membuat garis anggaran bergeser ke kanan yakni garis AC. Sehingga dapat dikatakan bahwa pengeluaran pemerintah dapat memperluas pilihan manusia tidak hanya untuk meningkatkan pendapatan mereka. Di antara berbagai pilihan tersebut, pilihan yang terpenting adalah untuk berumur panjang dan sehat, untuk berilmu pengetahuan dan untuk mempunyai akses terhadap sumber daya yang di butuhkan agar dapat hidup secara layak.

\section{KERANGKA KONSEP PENELITIAN}

Perlunya perhatian pemerintah terhadap investasi dibidang sumber daya manusia (human capital) dalam bidang kesehatan dan pendidikan diharapkan dapat memberikan efek positif pada pembentukan modal manusia, serta dapat meningkatkan pertumbuhan ekonomi sekaligus mempromosikan kesetaraan dan mengurangi kemiskinan (Gupta, 1998; Widodo, 2011, Razmi, 2012). Selain itu bidang infrastruktur diharapkan dapat meningkatkan akses masyarakat dan pada akhirnya dapat meningkatkan pendapatannya (Craigwell, 2012; Widodo, 2011; Fattah, 2012).

Dari uraian di atas dapatlah dibuat kerangka pemikiran seperti tampak pada gambar 3 .

\section{Hipotesis}

Secara teori dan bukti empiris pengeluaran pemerintah di sektor kesehatan, pendidikan dan infrastruktur sangat diperlukan, utamanya untuk meningkatkan kualitas hidup manusia, maka hipotesis yang diambil dalam penelitian ini yaitu diduga bahwa pengeluaran pemerintah di bidang pendidikan,bidang kesehatan dan bidang infrastruktur berpengaruh positif dan signifikan terhadap IPM Kabupaten/Kota di Propinsi Jawa Timur.

\section{METODE}

Penelitian ini menggunakan data panel yang merupakan gabungan antara antara data cross-section dan time series (Baltagi, 2005) dan metode regresi panel yang mempelajari pengaruh antara pengeluaran

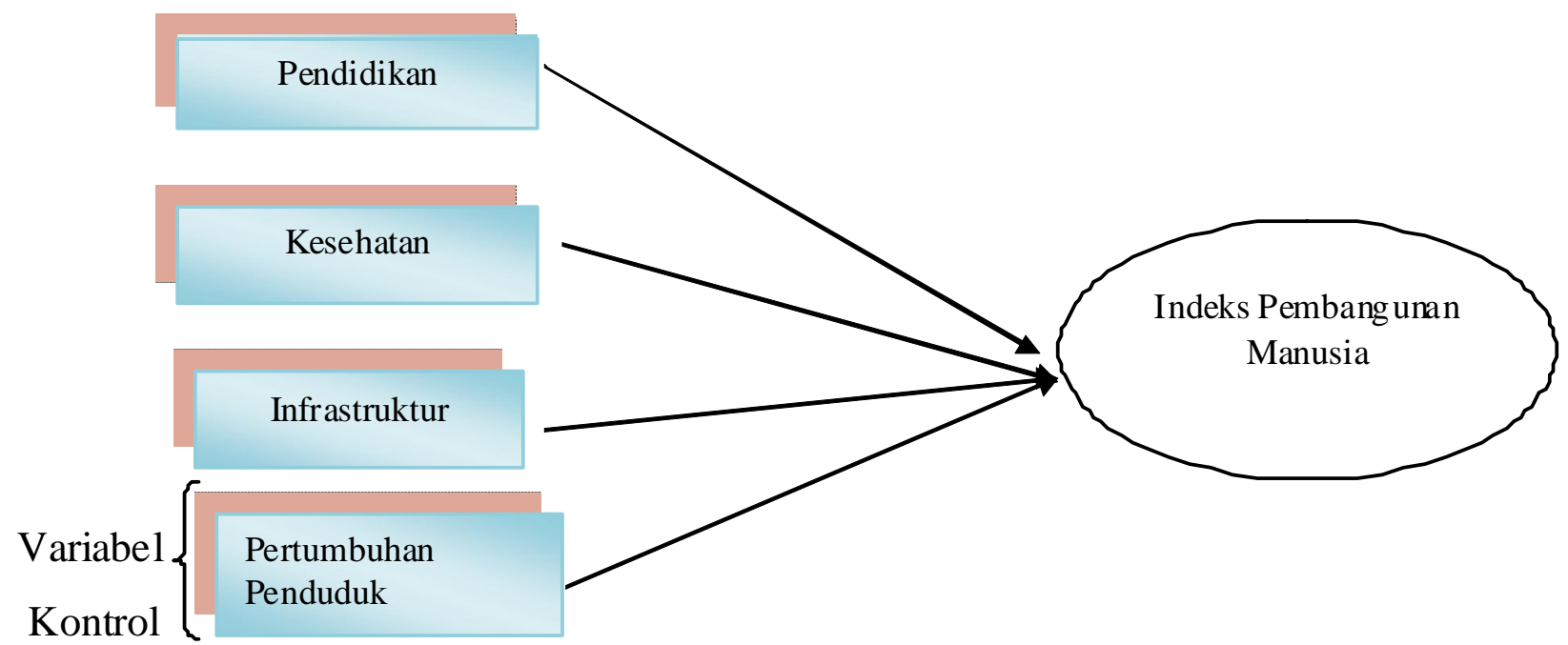

Gambar 3. Kerangka Konsep Penelitan

Sumber: Penulis, 2014 
pendidikan, kesehatan dan infrastruktur (jalan) serta pertumbuhan penduduk dengan pembangunan manusia selama periode 2007-2012 di 38 Kabupaten/Kota Jawa Timur, maka model untuk persamaan diatas dapat diformulasikan:

$Y_{i t}=\alpha+\beta_{1} X_{1 i t}+\beta_{2} X_{2 i t}+\beta_{3} X_{3 i t}+\beta_{4} X_{4 i t}+\varepsilon_{i t}$ Di mana $\mathrm{Y}_{i t}$ adalah IPM kabupaten/kota ke $i$ tahun ke $t, \mathrm{X}_{1}$ adalah Pengeluaran Pemerintah di bidang pendidikan kabupaten/kota ke $i$ tahun ke $t, \mathrm{X}_{2}$ adalah Pengeluaran Pemerintah di bidang kesehatan kabupaten/kota ke $i$ tahun ke $t, \mathrm{X}_{3}$ adalah Pengeluaran Pemerintah di bidang infrastruktur kabupaten/kota ke $i$ tahun ke $t, \mathrm{X}_{4}$ adalah Pertumbuhan Penduduk kabupaten/kota ke $i$ tahun ke $t$ sebagai variable kontrol, $\alpha$ adalah koefisien intersep, $\beta$, adalah koefisien slope, $\varepsilon_{i t}$ adalah error dengan $\mathrm{E}\left(\varepsilon_{i t}\right)=0, \mathrm{E}\left(\varepsilon_{i t}{ }^{2}\right)=\sigma^{2}, \mathrm{E}\left(\varepsilon_{i t}\right.$, $\left.\varepsilon_{j i}\right)=0$ untuk $\mathrm{i} \neq \mathrm{j}$, di mana $i=1,2, \ldots, \mathrm{N}$ dan $j=1$, $2, \ldots$, Kserta $t=1,2, \ldots, \mathrm{T}$

Perlu dicatat bahwa data pada indeks pembangunan manusia dan pertumbuhan penduduk diperoleh dari Badan Pusat Statistik. Sedangkan data pengeluaran pemerintah diperoleh dari Departemen Keuangan dan BPK RI. Dalam penelitian ini ditambahkan pertumbuhan penduduk sebagai variabel kontrol, sebab Jawa Timur merupakan propinsi terbanyak penduduknya nomor tiga setelah Jawa Barat.

\section{HASIL DAN PEMBAHASAN}

\section{Hasil}

Berdasarkan hasil uji Hausman model panel terbaik yang digunakan dalam penelitian ini adalah model fixed effects. Dalam model ini, semua koefisien estimasi secara statistik signifikan pada tingkat $5 \%$, hasilnya dua variabel utama secara statistik berpengaruh signifikan serta satu variabel utama dan satu variabel kontrol secara statistik berpengaruh tidak signifikan. Hasil tes ini ditunjukkan pada Tabel 1.
Secara umum, model ini cukup baik digunakan, hal ini tercermin dari nilai $R$-square yang mencapai 0,981 . Nilai $R$-square ini menjelaskan bahwa variasi dari keempat variabel bebas yang digunakan dalam model, yaitu variabel $X_{1}, X_{2}, X_{3}$, dan $X_{4}$, mempunyai pengaruh yang kuat sebesar $98,1 \%$ terhadap variabel terikat yaitu indeks pembangunan manusia (IPM). Nilai koefisien determinasi dari variabel model yang terbentuk adalah 0.981 . Sedangkan 1,9\% keragaman IPM Kabupaten/Kota Jawa Timur dijelaskan oleh variabel lain di luar model.

Perhitungan menunjukkan bahwa pengeluaran pemerintah bidang pendidikan memiliki pengaruh positif dan signifikan $(+0,106)$ paling kuat terhadap indeks pembangunan manusia daripada pengeluaran pemerintah bidang kesehatan $(+0,061)$.

\section{Pembahasan}

\section{Pengaruh Variabel Pengeluaran Pemerintah Bidang Pendidikan terhadap IPM}

Variabel pengeluaran pemerintah bidang pendidikan berpengaruh positif dan signifikan terhadap IPM di Jawa Timur dengan koefisien sebesar $(+0,106)$. Hasil penelitian ini memperkuat temuan dari Fattah (2012); Gupta, et al. (1998), Craigwel (2012), Guisan (2010) yang mengatakan bahwa investasi publik sektor pendidikan dapat meningkatkan kualitas modal manusia yang akan meningkatkan produktivitas dan pada akhirnya dapat mengurangi kemiskinan.

Besarnya perhatian Pemerintah Kabupaten/Kota di Jawa Timur terhadap pendidikan bisa dilihat dari makin besarnya anggaran yang dikeluarkan pemerintah dan terus berupaya agar amanah konstitusi yaitu anggaran untuk pendidikan minimal $20 \%$ dapat terealisasi secara baik (UU No 20 Tahun 2003). Juga dari makin banyaknya realisasi program-program pendidikan seperti pendidikan gratis untuk Sekolah Dasar

Tabel 1. Hasil Pemodelan dengan Fixed Effect Model

\begin{tabular}{ccccc}
\hline Variabel & Koefisien $\boldsymbol{\beta}$ & $\mathbf{t}_{\text {hitung }}$ & $\begin{array}{c}\text { Signifikansi } \\
(\boldsymbol{p} \text {-value })\end{array}$ & Keterangan \\
\hline Konstanta & 65,429 & 133,063 & $<0,001$ & Signifikan \\
PENDIDIKAN $\left(\mathrm{X}_{1}\right)$ & 0,106 & 12,384 & $<0,001$ & Signifikan \\
KESEHATAN $\left(\mathrm{X}_{2}\right)$ & 0,061 & 2,708 & 0,007 & Signifikan \\
INFRASTRUKTUR $\left(\mathrm{X}_{3}\right)$ & 0,020 & 0,617 & 0,538 & Tidak Signifikan \\
PP $\left(\mathrm{X}_{4}\right)$ & 0,119 & 0,631 & 0,529 & Tidak Signifikan \\
\hline R square & \multicolumn{3}{c}{$=0,981$} & \\
Adjusted R Square & $=0,977$ & \\
Jumlah Kuadrat Galat & $=98,528$ & \\
\hline
\end{tabular}

Sumber: Data Diolah 
dan Sekolah Menengah Pertama. Komitmen pemerintah dalam meningkatkan kualitas manusia dituangkan dalam Rencana Pembangunan Jangka Panjang Daerah (RPJPD) Tahun 2005-2025 dan dalam Rencana Pembangunan Jangka Menengah Daerah Provinsi Jawa Timur Tahun 2009-2014. Melalui program dan kegiatan yang didasarkan pada RPJPD dan RPJMD propinsi tersebut setiap Kabupaten/Kota di Jawa Timur wajib menindaklanjuti dengan program dan kegiatan yang menjamin terselenggaranya wajib belajar minimal pada jenjang pendidikan dasar dengan biaya yang serendah-rendahnya atau tanpa memungut biaya.

\section{Pengaruh Variabel Pengeluaran Pemerintah Bidang Kesehatan terhadap IPM}

Variabel pengeluaran pemerintah bidang kesehatan berpengaruh positif dan signifikan terhadap IPM di Jawa Timur dengan koefisien sebesar $(+0,061)$. Hasil penelitian ini memperkuat penelitian dari Rajkumar (2008), Khausal (2013),dan Kim (2013), menunjukkan bahwa peningkatan dari pengeluaran kesehatan secara signifikan menurunkan angka kematian bayi dan meningkatkan harapan hidup, dan dapat mengendalikan kondisi sosial-ekonomi di negara-negara tertentu. Razmi (2012) menemukan bahwa peningkatan kesehatan dapat meningkatkan produktivitas tenaga kerja.

Keseriusan pemerintah daerah terhadap masalah kesehatan didaerahnya terlihat dalam seberapa besar mengalokasikan anggaran kesehatan. Rata-rata pengeluaran pemerintah bidang kesehatan di Kabupaten/Kota Jawa Timur telah mengalokasikan lebih dari 10 persen dari total APBD, kecuali tahun 2007 hanya sebesar $8,95 \%$. Pelayanan kesehatan gratis yang diberikan pemerintah daerah di Jawa Timur melalui Jaminan Kesehatan daerah (Jamkesda) dalam mendukung program pemerintah pusat yaitu Jaminan Kesehatan Masyarakat (Jamkesmas) sejak tahun 2005 dan Jaminan Persalinan (Jampersal) yang baru dilaksanakan tahun 2011. Jumlah fasilitas kesehatan di Jawa Timur pada tahun 2008 meningkat dibanding tahun 2007. Pada 2008 tercatat terdapat 223 rumah sakit umum; 938 puskesmas; 2.280 puskesmas pembantu; 1.175 puskesmas keliling; 5.425 Pondok Bersalin Desa (polindes); dan 44.636 Pos Pelayanan Terpadu (posyandu). Rasio jumlah puskesmas terhadap penduduk sebesar 1:39.677 jiwa.Rata-rata setiap puskesmas memiliki 1-2 puskesmas pembantu (RPJMD Jatim 2009-2014).

\section{Pengaruh Variabel Pengeluaran Pemerintah Bidang Infrastruktur terhadap IPM}

Variabel pengeluaran pemerintah bidang infrastruktur jalan berpengaruh tidak signifikan terhadap IPM di Jawa Timur.Hasil penelitian ini mendukung temuan Badrudin (2011), yang mengatakan bahwa infrastruktur yang diproksi dengan transportasi darat di Daerah Istimewa Yogyakarta (DIY) tidak berpengaruh tehadap IPM karena masyarakat DIY mempunyai budaya sense of education yang tinggi.

Meskipun Jawa Timur adalah salah satu provinsi yang memiliki jalan kabupaten/kota terpanjang di Indonesia, namun ketersediaan infrastruktur di Jawa Timur masih jauh dari yang diharapkan. Hal ini disebabkan oleh kecilnya investasi pemerintah daerah dalam infrastruktur masih dibawah 1 persen dari PDRB Jawa Timur. World Bank (2011) memperkirakan bahwa Indonesia membutuhkan investasi sekitar 5 persen dari PDB setiap tahun dalam sektor infrastruktur publik, yang sebagian besar di tingkat lokal, untuk mempertahankan sasaran pertumbuhan ekonomi jangka menengah sebesar 6\%. Tren pertumbuhan belanja infrastruktur Jawa Timur (Provinsi, Kabupaten/Kota, Pusat) tidak dapat mengimbangi pertumbuhan PDRB Jawa Timur. Secara rata-rata, belanja infrastruktur di Jawa Timur hanya sekitar $0,7 \%$ dari PDRBnya. Rendahnya investasi di bidang infrastruktur akan berdampak pada rendahnya daya saing dan proses produksi negara tertentu yang berdampak pada terciptanya ketidakadilan dalam distribusi sosial (gambar 4).

\section{Pengaruh Variabel Kontrol Pertumbuhan Penduduk terhadap IPM}

Variabel kontrol pertumbuhan penduduk berpengaruh tidak signifikan terhadap IPM di Jawa Timur.Hasil penelitian ini bertentangan dengan penelitian Hamzah et al(2012), Ahmad et al(2012) dan Haghhenas et al (2007) yang mengatakan bahwa pertumbuhan penduduk memiliki pengaruh signifikan, namun memiliki arah yang negatif. Jumlah penduduk yang besar, distribusi penduduk yang tidak merata dengan kualitas rendah, membuat penduduk menjadi beban bagi pembangunan dan akan menurunkan IPM.

Jumlah penduduk Jawa Timur tergolong besar, menduduki rangking ketiga di Indonesia setelah Jawa Barat. Jika kita lihat kondisi penduduk Jawa Timur dari komposisi umur sejak tahun 2007-2012 jumlah 


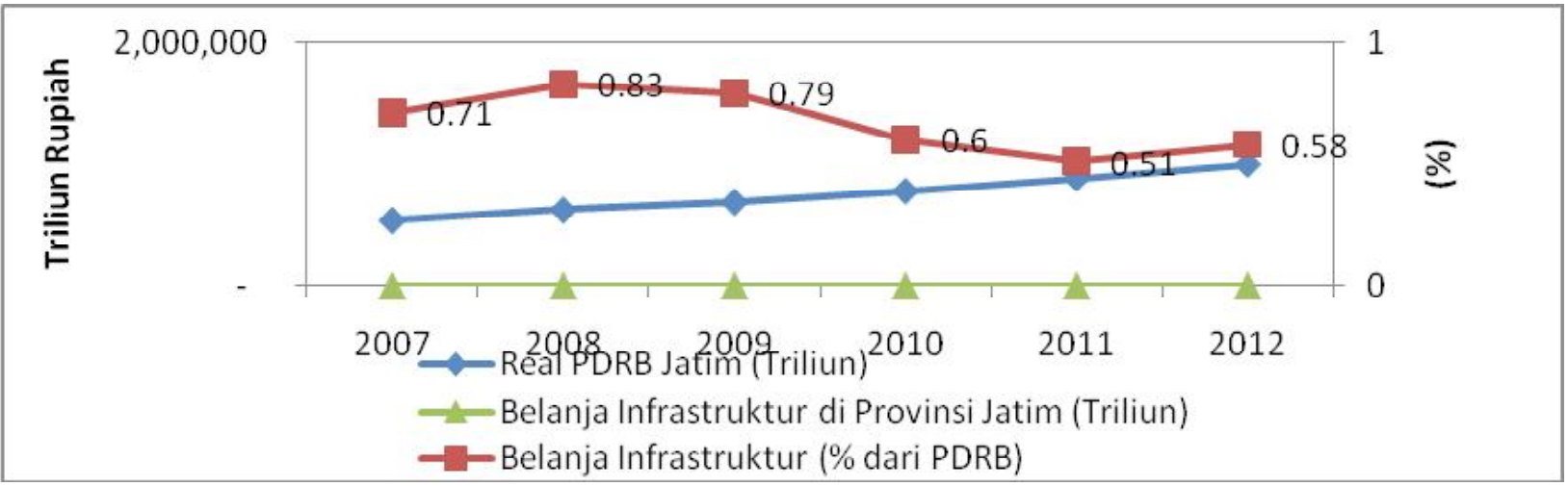

Gambar 4. Investasi Pemerintah Daerah dalam Infrastruktur Tahun 2007-2012

Sumber: DJPK, 2007-2012 (data diolah)

penduduk pada kelompok usia produktif (umur 1564 tahun) lebih banyak dibandingkan jumlah penduduk kelompok usia non-produktif (umur 0-14 tahun dan 65 tahun ke atas), hal ini dapat memberikan manfaat bagi pembangunan nasional terutama pada sektor ekonomi, jika disertai dengan peningkatan kualitas sumber daya manusia (SDM) secara maksimal melalui pendidikan, pelayanan kesehatan dan penyediaan lapangan pekerjaan.

\section{KESIMPULAN DAN SARAN}

\section{Kesimpulan}

Dari hasil analisis penelitian mengenai pengaruh pengeluaran pemerintah daerah terhadap indeks pembangunan manusia di Jawa Timur tahun 2007-2012 dapat disimpulkan sebagai berikut: (1) Pengeluaran pemerintah bidang pendidikan selama periode 20072012 telah menunjukkan pengaruh positif dan signifikan

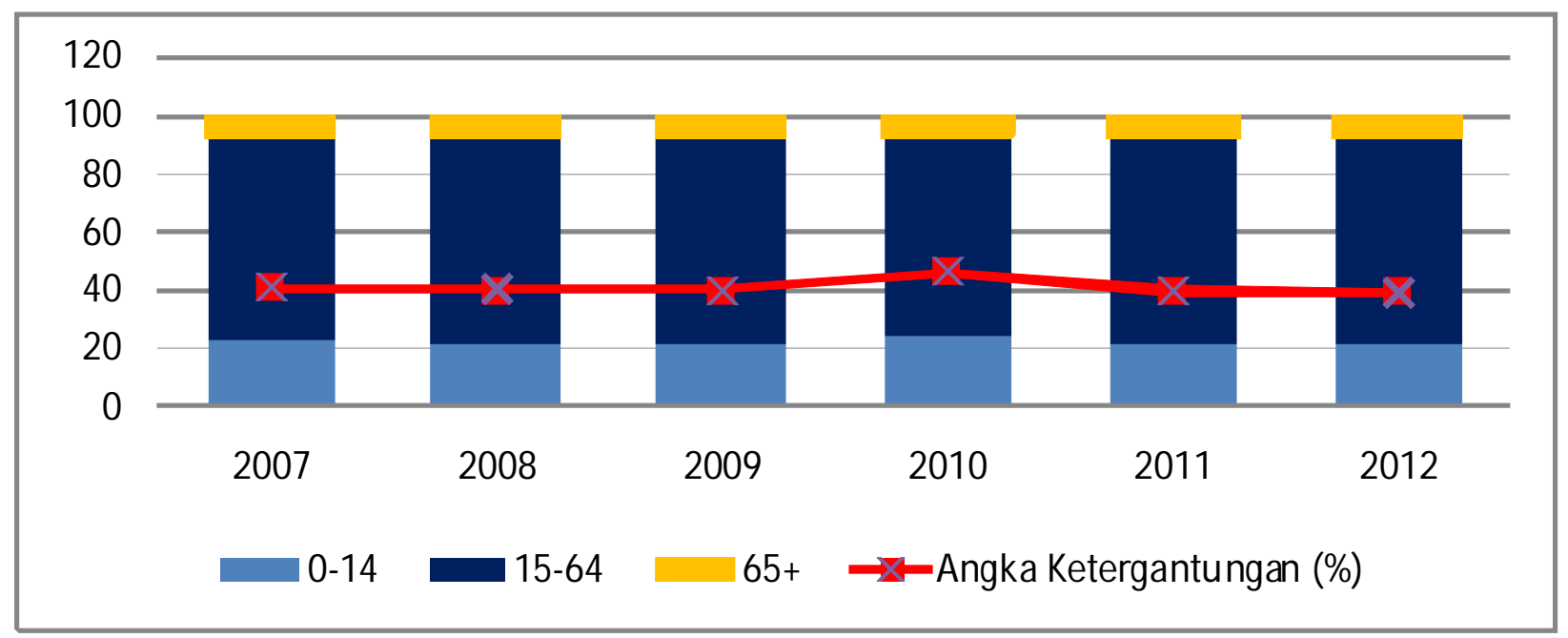

Gambar 5. Komposisi Penduduk menurut Kelompok Umur di Jawa Timur Tahun 2007-2012

Sumber: BPS Provinsi Jatim, 2010-2012 (data diolah)

Menurut penelitian terbaru Gupta, et al. (2011) menemukan bahwa rasio ketergantungan yang rendah (seperti penurunan kesuburan) menciptakan kesempatan untuk meningkatkan produktivitas, tabungan dan investasi dalam pertumbuhan di masa depan. Hasil penelitian menemukan bahwa kesuburan yang lebih rendah dikaitkan dengan kesehatan anak dan capaian pendidikan yang lebih baik, dan partisipasi angkatan kerja yang lebih besar bagi perempuan. terhadap IPM. Hasil ini sesuai dengan teori yang mengatakan bahwa pengeluaran pemerintah bidang pendidikan akan meningkatkan kualitas sumberdaya manusia. Ada dua hal yang dapat menjelaskan dari hasil tersebut, yaitu: (i) realisasi anggaran bidang pendidikan Kabupaten/Kota di Jawa Timur telah sesuai dengan amanah konstitusi yaitu anggaran untuk pendidikan minimal $20 \%$ dapat terealisasi secara baik; dan (ii) meningkatnya angka rata-rata lama sekolah dan angka melek huruf sebagai indikator indeks 
pendidikan. (2) Begitu juga dengan pengeluaran pemerintah bidang kesehatan selama periode 20072012 juga menunjukkan pengaruh positif dan signifikan terhadap IPM. Meningkatnya realisasi anggaran bidang kesehatan seiring dengan peningkatan angka harapan hidup yang memberikan pengaruh besar terhadap IPM. (3) Hasil yang berbeda didapat pada pengeluaran pemerintah di bidang infrastruktur yang diproxy jalan. Hasilnya menunjukkan pengaruh yang positif namun tidak signifikan. Hal ini disebabkan oleh tren investasi pemerintah dalam infrastruktur, belum mampu mengimbangi pertumbuhan PDRB Jawa Timur. (4) Sedangkan pengaruh pertumbuhan penduduk sebagai variabel kontrol dalam penelitian ini menunjukkan pengaruh yang positif namun tidak signifikan. Tidak signifikan ini disebabkan oleh komposisi penduduk usia produktif lebih besar dari penduduk usia non produktif yang menyebabkan rasio ketergantungan rendah.

\section{Saran}

Dalam rangka meningkatkan IPM Jawa Timur, perlu dilakukan pemerataan fasilitas pendidikan dan kesehatan, yang secara spesifik dilakukan dengan dua mekanisme: (1) Pengeluaran pemerintah bidang pendidikan dapat lebih difokuskan pada peningkatan fasilitas-fasilitas penunjang pendidikan terutama pada jenjang SMP dan SMA mengingat APS SD hampir mencapai $100 \%$, selain itu dana Bantuan operasional sekolah (BOS) dan Bantuan siswa miskin (BSM) perlu ditingkatkan untuk mewujudkan pendidikan gratis pada program WAJAR 9 tahun dan selanjutnnya 12 tahun, serta program peningkatan mutu untuk meningkatkan kapasitas pegawai dan tenaga pendidik. (2) Sedangkan di bidang kesehatan lebih difokuskan pada program pemberian kesehatan gratis bagi masyarakat khususnya masyarakat miskin serta program promosi kesehatan. Selain itu, perlu dilakukan peningkatan kerjasama antara tenaga medis professional dan tenaga medis lokal tradisional mengingat sebagian penduduk Jawa Timur lebih percaya terhadap tenaga medis lokal tradisional. (3) Untuk mendukung program-program tersebut di atas pemerintah diharapkan dapat melibatkan LSM atau lembaga sosial untuk bersama-sama meningkatkan pola pikir dan kesadaran masyarakat akan pentingnya pendidikan dan kesehatan.

Dalam mengatasi keterbatasan dana dan pemerataan ketersediaan infrastruktur khususnya jalan, maka dibutuhkan sumber-sumber pendanaan Iain, seperti menggunakan skema Public Private
Partnership (PPP) di mana Skema ini mengacu pada Kementerian Keuangan Republik Indonesia yang menerbitkan kebijakan terkait Viability Gap Fund melalui Peraturan Menteri Keuangan Nomor 223/ PMK/011/2012 tentang Pemberian Dukungan Kelayakan atas Sebagian Biaya Konstruksi pada Proyek Kerja Sama Pemerintah dengan Badan Usaha dalam Penyediaan Infrastruktur. Kebijakan fiskal ini ditujukan untuk: (i) meningkatkan kelayakan finansial Proyek Kerja Sama sehingga menimbulkan minat dan partisipasi Badan Usaha pada Proyek Kerja Sama; (ii) meningkatkan kepastian pengadaan Proyek Kerja Sama dan pengadaan Badan Usaha pada Proyek Kerja Sama sesuai dengan kualitas dan waktu yang direncanakan; dan (iii) mewujudkan layanan publik yang tersedia melalui infrastruktur dengan tarif yang terjangkau oleh masyarakat, sesuai Peraturan Presiden Nomor 56 Tahun 2011 tentang perubahan kedua atas Peraturan Presiden Nomor 67 Tahun 2005 tentang Kerjasama Pemerintah dengan Badan Usaha dalam Penyediaan Infrastruktur.

\section{DAFTAR RUJUKAN}

Ahmad, N., Luqman, M., Hayat, F., Muhammad, A.A. 2012. The Impact of Trade Liberalization Population Growth and Income Inequality on Poverty: A Case Study of Pakistan, volume 5.

Backman, G., Hunt, P., Khosla, R., et al. 2008.Health Systems and The Right To Health: an Assessment of 194 Countries, The Lancet, 372, pp. 2047-2085.

Badan Pusat Statistik (BPS). 2010. Jawa Timur Dalam Angka. Diakses dari http://jatim.bps.go.id pada tanggal 23 Januari 2014.

Badan Pusat Statistik (BPS). 2011. Jawa Timur Dalam Angka. Diakses dari http://jatim.bps.go.id pada tanggal 23 Januari 2014.

Badan Pusat Statistik (BPS). 2012. Jawa Timur Dalam Angka. Diakses dari http://jatim.bps.go.id pada tanggal 23 Januari 2014.

Badrudin, R. 2011. Pengaruh Pendapatan dan Belanja Daerah terhadap Pembangunan Manusia di Propinsi Daerah Istimewa Yogyakarta. Buletin Ekonomi Jurnal Manajemen, Akuntansi, dan Ekonomi Pembangunan, Vol. 9, No.1.

Baltagi, B.H. 2005. Econometrics Analysis of Data Panel, 3rd edition, John Wiley \& Sons Ltd., Chicester, England.

Fattah, S., Muji, A. 2012. Local Government Expenditure Allocation toward Human Development Index at Jeneponto Regency, South Sulawesi, Indonesia, IOSR Journal of Humanities And Social Science (JHSS) Volume 5, Issue 6 (Nov. - Dec.), PP40-50. 
Gupta, S., Clements, Benedict, and Tiongson, Erwin. 1998 Public Spending on Human Development. Finance \& Development.

Direktorat Jendral Perimbangan Keuangan (DJPK). 2007 2012. Data Keuangan Daerah. Diakses dari http://djpk. depkeu.go.id pada tanggal 23 Januari 2014.

Gupta, S., Clements, B., and Inchauste, G. (Eds). 2004. Helping Countries Develop: The Role of Fiscal Policy. International Monetary Fund, Washington, DC.

Gupta, D., Monica, B., John, Cleland, J. 2011. Population, Poverty, and Sustainable Development. A Review of the Evidence, Policy Research Working Paper 5719.

Guisan, M.C. 2009. Indicators of Social Well-Being, Education and Genre Equality and World Development: Analysis of 132 Countries. International Journal of Applied Econometrics and Quantitative Studies, Vol. 6-2, pp.5-24.

Guisan, M.C. 2010. Health Expenditure, Education, Government Effectiveness and Quality of Life in Africa and Asia. Regional and Sectoral Economic Studies Vol. 10-1.

Haghshenas, M., Nader, S., Arezo, Sahel, T., \& Salehi, N. 2007. Population Dynamics and Human Development Indices in Selected African Countries: Trends and Levels. Population Studies and Research Center for Asia and the Pacific Tehran, IRAN.

Hamzah, Z., Muhammad, R., Renny, S., Eleonora. 2012. Human Development Quality And Its Problems In Indonesia. OIDA International Journal of Sustainable Development 05:07.

Kim, K.T., Lane, R., Shannon. 2013. Government Health Expenditure and Public Health Outcomes: AComparative Study among 17 Countries and Implications for US Health Care Reform, American International Journal of Contemporary Research. Vol. 3 No. 9.

Kaushal, K., Kaushalendra, R., F. Ram, Faujdar, Abhishek, S., Abhishek. 2013. Public Spending on Health and Childhood Mortality in India, MPRA Paper No 48680.

Kusharjanto, H., Kim, D. 2011. Infrastructure and Human Development: The Case of Java, Indonesia, Journal of the Asia Pacific Economy, Vol. 16, No. 1
Mangkoesoebroto, G. 2012. Ekonomi Publik, Edisi Ketiga. Yogyakarta: BPFE.

Prud'homme, R. 2004. Infrastruktur and Development, Paper prepared for the ABCDE (Annual Bank Conference on Development Economics), Washington.

Razmi, J., Mohammad. 2012. Investigating the Effect of Government Health Expenditure on HDI in Iran, Journal of Knowledge Management, Economics and Information Technology.

Ranis, G., and Stewart, F. 2010. Success and Failure in Human Development, 1970-2007, UNDP Human Development Reports Research Paper July.

Rajkumar, S., Andrew. Swaroop, V. 2008. Public Spending and Outcomes: Does Governance Matter? Journal of Development Economics 86.

Peraturan Gubernur Jawa Timur Nomor 38 Tahun 2009 tentang Rencana Pembangunan Jangka Menengah Daerah (RPJMD) Provinsi Jawa Timur 2009-2014.

Saraswati, E. 2012. Public Spending Education and Inequality: A Case Study in Indonesia, International Journal of Social Science and Humanity, Vol. 2, No. 5.

Sukirno, S. 2004. Makroekonomi, Teori Pengantar, Edisi Ketiga. Jakarta: Raja Grafindo.

Todaro, M., Smith, C. 2006. Pembangunan Ekonomi. Edisi Kesembilan Jilid 1, Penerbit Erlangga.

Undang-Undang Nomor 38 Tahun 2004 tentang Jalan.

Undang-Undang Pendidikan Nomor 20 Tahun 2003 Tentang Sistem Pendidikan Nasional.

Undang-Undang Nomor 36 Tahun 2009 Tentang Kesehatan

UNDP, 1990. Human Development Report 1990. New York: UNDP.

Widodo, A., Waridin, dan Maria, K., Johanna. 2011. Analisis Pengaruh Pengeluaran Pemerintah di Sektor Pendidikan dan Kesehatan terhadap Pengentasan Kemiskinan melalui Peningkatan Pembangunan Manusia di Provinsi Jawa Tengah, Jurnal Dinamika Ekonomi Pembangunan Volume 1, Nomor 1.

World Bank. 2011. Ringkasan Eksekutif Analisa Pengeluaran Pubik Jawa Timur 2011. 